\title{
PERAN PEMERINTAH DAERAH DALAM PENGEMBANGAN USAHA MIKRO KECIL DAN MENENGAH (UMKM) "HANDYCRAFT" LIMBAH KAYU JATI SEBAGAI PRODUK UNGGULAN KABUPATEN BOJONEGORO
}

\section{Marantika Fibrianti Sumadi dan Ananta Prathama}

Universitas Pembangunan Nasional (UPN) Veteran Jawa Timur, Indonesia

Email: marantikasumadi@gmail.com dan prathama.ananta@gmail.com

\section{Abstract}

The achievement of national development standards can be seen from education, health and welfare. An indication of the achivment of national development is through economic development. Economic development is the responsibility of the central government, local government and the people who use resources to meet community needs. One of them is from the MSMe sector, in developing MSMSe this is the authority of the central government and local governments in regulating regional autonomy. So that the role of local governments in the development of MSMEs is an important factor. The purpose of this study is to find out, the role of local government in development SMEs handycraft teak wood waste as the superior product of Bojonegoro. This research focuses on the application of the role government in developing effective and optimal SMEs proposed by Gede Diva. The research method used is descriptive qualitative method. Data collection techniques using interview and observation techniques to obtain qualitative data, as well as documentation techniques used to obtain valid images in the field. The results showed that the role of the government in the development of SMEs using the theory of Gede Diva was quite a role. Evidenced by the three focus, the role of the government as a facilitator, regulator, and katalisator that has been play a role in development of wood waste handycraft SMEs as a superior product of Bojonegoro.

Keywords: the role of government; MSMEs
Abstrak
Pencapaian standar pembangunan nasional dapat dilihat dari pendidikan, kesehatan dan kesejahteraan. Indikasi achivment pembangunan nasional adalah melalui pembangunan ekonomi. Pembangunan ekonomi menjadi tanggung jawab pemerintah pusat, pemerintah daerah dan masyarakat yang menggunakan sumber daya untuk memenuhi kebutuhan masyarakat. Salah satunya dari sektor UMKM, dalam mengembangkan UMKM ini merupakan kewenangan pemerintah pusat dan pemerintah daerah dalam mengatur otonomi daerah. Sehingga peran pemerintah daerah dalam pengembangan UMKM menjadi faktor penting. Tujuan penelitian ini adalah untuk mengetahui, peran pemerintah daerah dalam pengembangan UKM kerajinan limbah kayu jati sebagai produk unggulan Bojonegoro. Penelitian ini berfokus pada penerapan peran pemerintah dalam mengembangkan UKM yang efektif dan optimal yang diusulkan oleh Gede Diva. Metode penelitian yang

$\begin{array}{ll}\text { How to cite: } & \text { Sumadi, Marantika } \\ & \text { Pengembangan Usa } \\ & \text { Produk Unggulan K } \\ & \text { literate.v6i5.2701 } \\ \text { E-ISSN: } & 2548-1398 \\ \text { Published by: } & \text { Ridwan Institute }\end{array}$


Peran Pemerintah Daerah dalam Pengembangan Usaha Mikro Kecil dan Menengah (UMKM) "Handycraft" Limbah Kayu Jati Sebagai Produk Unggulan Kabupaten

Bojonegoro

digunakan adalah metode kualitatif deskriptif. Teknik pengumpulan data menggunakan teknik wawancara dan observasi untuk mendapatkan data kualitatif, serta teknik dokumentasi yang digunakan untuk mendapatkan gambar yang valid di lapangan. Hasil penelitian menunjukkan bahwa peran pemerintah dalam pengembangan UKM menggunakan teori Gede Diva cukup berperan. Dibuktikan dengan tiga fokus tersebut, peran pemerintah sebagai fasilitator, regulator, dan katalisator yang selama ini berperan dalam pengembangan UKM kerajinan limbah kayu sebagai produk unggulan Bojonegoro.

Kata Kunci: peran pemerintah; UMKM

\section{Pendahuluan}

Pembangunan nasional yang merupakan bentuk tercapainya standar kualitas hidup bagi masyarakat dalam hal pendidikan, kesehatan dan kesejahteraan (Ali, 2009). Pembangunan nasional salah satunya dengan dilakukannya pembangunan dari segi perekonomian yang bertujuan untuk kesejahteraan masyarakat. Indikasi tercapainya suatu pembangunan ekonomi yaitu dari peningkatan segi perekonomian, kesempatan kerja yang luas, minimnya tingkat pengangguran dan kemiskinan. Pembangunan ekonomi ini menjadi tanggung jawab pemerintah daerah serta masyarakat yang mengelola dari sumber daya yang ada untuk memenuhi segala kebutuhan masyarakat yaitu produk-produk yang sudah dihasilkan. Untuk itu dari sector UMKM, merupakan kegiatan wirausaha ekonomi yang bisa dimiliki baik satu orang maupun kelompok sesuai dengan peraturan undang-undang. Dalam pengembangan UMKM menjadi tanggung jawab pemerintah pusat serta pemerintah daerah juga memiliki peran dan wewenang yang besar dalam mengatur otonomi daerah.

Pemerintah daerah yang melakukan pengembangan terhadap UMKM dalam meningkatkannya pertumbuhan ekonomi di daerah yaitu salah satunya pemerintah daerah kabupaten Bojonegoro. Dengan banyaknya jumlah UMKM di Kabupaten Bojonegoro sehinga harus adanya pengembangan dan bimbingan dari pemerintah daerah. Salah satu UMKM yang unggul yaitu kerajinan dari kayu jati, karena Kabupaten Bojonegoro memiliki hutan jati dengan luas area mencapai 93.833,36 Ha (Badan Pusat Statistika, n.d.). Hal tersebut merupakan sumber daya yang menjadi salah satu potensi unggulan kabupaten Bojonegoro adalah kayu jati (Agro Bisnis, 2019). Potensi ini telah dimanfaatkan oleh masyarakat Bojonegoro sebagai sumber usaha dengan berbahan dasar kayu jati.

Adapun daerah-daerah yang terkenal sebagai indutri kayu jati diantaranya mebel atau furniture jati yaitu Desa Sukorejo dan Temayang yang diklaim beda dengan yang lain sebab furniture Bojonegoro berbahan kayu jati yang sudah tua jadi menghasilakn furniture kuat dan ukiran indah yang memberikan corak khas. Sedangkan perajin akar jati atau gembol dari Desa Meduri kecamatan Margomulyo. Selain itu limbah kayu jati dimanfaatkan oleh warga desa Desa Batokan Kecamatan Kasiman, Bojonegoro yaitu handycraft dari bubut kayu jati asli dari Bojonegoro (Agro Bisnis, 2019). 
Pada penelitian ini akan memfokuskan di salah satu UMKM yaitu Handycraft kayu jati di Kecamatan Kasiman karena kerajinan tangan berbahan dasar limbah-limbah potongan kayu jati sehingga diolah menjadi berbagai jenis produk seperti hiasan dinding, jam dinding, tempat tisu, tempat gelas, vas bunga,toples kayu, miniature dan lain-lain. Dengan mengandalkan limbah potongan kayu jati dapat dijadikan suatu produk kerajinan tangan yang mempuyai nilai jual yang tinggi. Hasil potongan limbah kayu jati yang diperoleh dari pabrik atau tempat pembuatan furniture mebel yang sebelumnya berupa kayu jati gelondongan dan limbahnya yang sudah tidak terpakai digunakan sebagai kerajinan tangan atau handycraft.

\section{Tabel 1}

Data jumlah Usaha Industri Kerajinan Rumah Tangga di Kecamatan Kasiman Tahun 2019

\begin{tabular}{lccccccc}
\hline Desa/Kelurahan & Tempe & Tahu & Roti & Anyaman & Mebel & $\begin{array}{c}\text { Penggiling } \\
\text { Padi }\end{array}$ & $\begin{array}{c}\text { Kerajinan } \\
\text { Kayu }\end{array}$ \\
\hline Batokan & 3 & 2 & 4 & 0 & 4 & 0 & 174 \\
Betet & 1 & 1 & 4 & 0 & 6 & 1 & 46 \\
Tembeling & 2 & 1 & 0 & 0 & 2 & 4 & 10 \\
Sidomukti & 1 & 0 & 4 & 1 & 0 & 3 & 0 \\
Besah & 1 & 1 & 0 & 0 & 0 & 5 & 18 \\
Sambeng & 2 & 2 & 3 & 0 & 5 & 2 & 12 \\
Ngaglik & 2 & 1 & 0 & 0 & 0 & 0 & 4 \\
Kasiman & 1 & 1 & 0 & 0 & 3 & 0 & 6 \\
Sekaran & 2 & 1 & 0 & 2 & 4 & 1 & 0 \\
Tambakmerak & 1 & 0 & 0 & 0 & 2 & 1 & 0 \\
Jumlah & 16 & 10 & 15 & 3 & 26 & 17 & 270 \\
\hline
\end{tabular}

Sumber: bojonegorokab.bps.go.id

Dari data tabel 1 menunjukan bahwa masyarakat di Desa Batokan Kecamatan Kasiman mampu memanfaatkan limbah kayu jati dengan inovasi dan ciri chas sehingga menjadi kerajinan tangan dengan memiliki nilai jual yang tinggi bahkan mampu menembus ekspor ke luar negeri.

Tahun 2020 Dinas Koperasi dan UMKM Kabupaten Bojonegoro mendapat kabar baik karena salah satu UMKM handycraft kayu jati dari Kecamatan Kasiman mendapat penghargaan juara 1 dalam lomba Perkoperasian dan UMKM berprestasi yang di adakan oleh Dinas Koperasi dan UKM Provinsi Jawa Timur. 


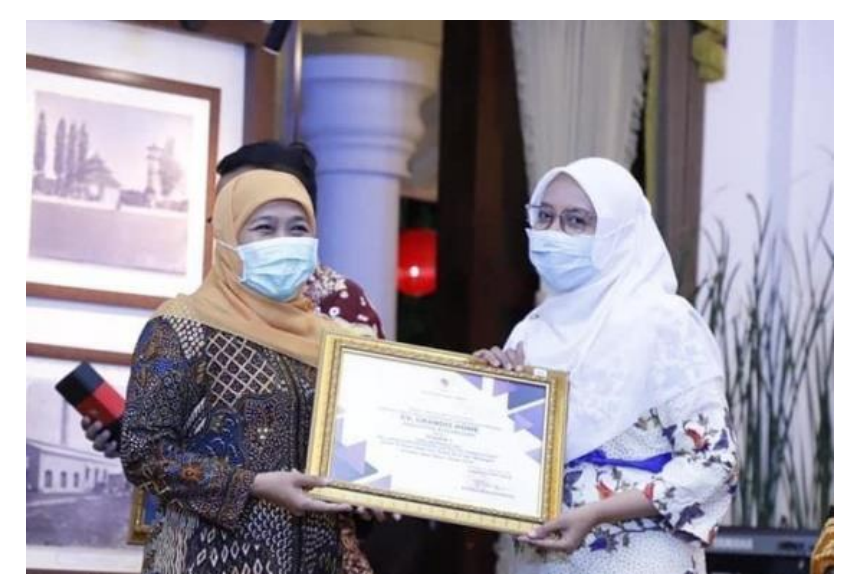

Gambar 1

Pemberian Penghargaan

Sumber: Diskopukm.jatimprov.go.id

Gambar diatas adalah Pemberian penghargaan Gubernur Jawa Timur kepada juara 1 UMKM berprestasi kategori Handycraft di Tingkat Jawa Timur. Hal ini membuktikan bahwa adanya peran pemerintah daerah Kabupaten Bojonegoro dalam perannya sebagai wadah yang memberikan naungan terhadap UMKM yang ada di Kabupaten Bojonegoro. Produk handycraft berbahan dasar dari limbah kayu jati dan serat alam juga mampu menembus pasar Asia dan Eropa, dan dengan ini mampu memperkerjakan tenaga kerja yang direkrut dari warga sekitar dengan melalui serangkaian pelatihan. Semua capaian itu tidak terlepas dari peran pemerintah daerah.

Sehingga dengan usaha kerajinan limbah kayu jati di Kecamatan Kasiman ini dapat menyerap tenaga kerja masyarakat sekitar untuk menambah pendapatan serta meningkatkan kesejahteraan masyarakat. Sejalan dengan pertumbuhan positif UMKM di Bojonegoro, beberapa faktor yang mempengaruhi para pelaku UMKM juga semakin kompleks. Adapun peran pemerintah daerah Kabupaten Bojonegoro khususnya Dinas Perindustrian, Dinas Perdagangan, Koperasi dan Usaha Mikro, bertanggung jawab menjalankan suatu kebijakan pemerintah daerah dalam program kerja untuk pengembangan UMKM.

Seperti dijelaskan oleh teori Gede Diva dalam pengembangan UMKM yang optimal dan efektif maka pemerintah memiliki peran yaitu sebagai fasilitator, regulator dan katalisator. Oleh karena itu peran dari pemerintah Kabupaten Bojonegoro selalu berupaya memberikan pelayanan atau pembinaan kepada UMKM Handycraft kayu jati di Kecamatan Kasiman yaitu dengan memberikan perlindungan, pembinaan atau sosialisasi dan pelatihan bagi pelaku UMKM, fasilitasi pengembangan usaha seperti halnya memberikan modal ataupun alat produksi, perluasan pemasaran, memberikan sosialisasi tentang sistem penyaluran kredit kur dengan suku bunga rendah, hal ini bertujuan supaya siap dan mampu dalam bersaing dengan produk lain. Memberikan pelatihan kepada pelaku UMKM agar dapat menciptakan suatu inovasi dalam kualitas 
produk, serta dilakukannya promosi. Sehingga pengembangan UMKM Handycraft kayu jati di Kabupaten Bojonegoro semakin berkembang pesat.

Penelitian terdahulu yaitu sudah dilakukan oleh pihak sebelumnya yang sudah pernah melakukan penelitian. Hal ini dilakukan untuk mengetahui relevansi, kesamaan dan perbedaan diantara penelitian terdahulu dengan penelitian yang kami lakukan. Penelitian pertama adalah penelitian dari (Putra, 2016) yang berjudul Peran Pemerintah Daerah Dan Partisipasi Pelaku Usaha Dalam Pengembangan UMKM Manik-Manik Kaca di Kabupaten Jombang. Tujuan penelitian ini adalah untuk mengetahui peran dari pemerintah dan partisipasi dari pelaku usaha dalam pengembangan Usaha Mikro Kecil Menengah manik-manik kaca di Kabupaten Jombang.

Hasil dari penelitian ini yaitu, peranan dari pemerintah dalam upaya mengembangkan UMKM manik-manik kaca di Kabupaten Jombang yaitu sebagai fasilitator meliputi pelatihan manajemen usaha dan proses produksi, bantuan sarana dan prasarana dan alat produksi. Peran pemerintah sebagai katalisator, meliputi penetapan manik-manik kaca sebagai produk unggulan kabupaten Jombang, promosi, bantuan pengurus HAKI, penyediaan modal bergulir. Sedangkan partisipasi pelaku usaha, dalam penelitian ini bahwa diwujudkan dari hadir dalam acara temu usaha, memberikan gagasan, mengikuti pameran, mengadakan kegiatan pelatihan, meningkatnya omzet ketika mengikuti pameran, usaha yang rapi pasca pelatihan manajemen usaha.

\section{Metode Penelitian}

Jenis penelitian ini menggunakan penelitian deskriptif melalui pendekatan kualitatif (Moleong, 2017). Metode deskriptif kualitatif bertujuan untuk meringkas, menggambarkan, situasi atau kondisi dari suatu keadaan dimasyarakat. Fokus penelitian ini yaitu peran pemerintah daerah dalam pengembangan UMKM handycraft limbah kayu jati sebagai produk unggulan Kabupaten Bojonegoro. Dasar teori yang digunakan yaitu teori menurut Gede Diva yang mengemukakan 3 peran pemerintah dalam pengembangan UMKM yang efektif dan optimal meliputi peran pemerintah sebagai fasilitator, regulator dan katalisator (Prof Sugiyono, 2015).

Sumber data penelitian ini yaitu meliputi buku, dokumen, berita, informan, dan lain-lain. Berdasarkan penelitian ini data diperoleh melalui observasi dan informan, meliputi dari data sekunder dan primer. Teknik dari pengumpulan data yang digunakan yaitu observasi, wawancara, pengamatan serta dokumentasi. Hal ini merupakan langkah utama untuk mendapatkan suatu data (P. D. Sugiyono, 2012). Teknik analisis data menggunakan dari Miles dan Huberman, analisis data kualitatif dengan melalui tahap kondensasi data, penyajian data, menarik kesimpulan atau verifikasi.

\section{Hasil dan Pembahasan}

Pada bagian ini akan menguraikan hasil dari penelitian yang data-datanya berasal dari lapangan sesuai dengan fokus penelitian. Peneliti sudah menetapkan menggunakan metode penelitian melalui tahap observasi, wawancara dan juga 
dokumentasi sehingga pada saat wawanacara sumber data yang diperoleh bersumber dari key person dan informan. Hasil penelitian membahas sesuai dengan fokusnya dan rumusan masalah penelitian yaitu Peran Pemerintah Daerah dalam Pengembangan UMKM Handycraft Limbah Kayu Jati sebagai Produk Unggulan Kabupaten Bojonegoro. Berikut uraian pembahasan penelitian berupa analisa data dengan menggunakan landasan teori, berurutan dengan masing-masing fokus dan sasaran kajian maka selanjutnya terdapat 3 fokus dalam penelitian ini dengan melihat peran pemerintah dalam pengembangan UMKM yaitu meliputi :

\section{A. Peran Pemerintah Daerah sebagai Fasilitator}

Sebagai fasilitator, pemerintah daerah mempunyai peran dalam memfasilitasi UMKM hal ini guna untuk mendorong pengembangan dan kemajuan UMKM. Dalam penjelasan UU No 20 tahun 2008 pasal 1 dinyatakan bahwa pengembangan adalah upaya yang dilakukan oleh Pemerintah,Pemerintah Daerah, Dunia Usaha,dan masyarakat untuk memberdayakan Usaha Mikro, Kecil, dan Menengah melalui pemberian fasilitas,bimbingan, pendampingan, dan bantuan perkuatan untuk menumbuhkan dan meningkatkan kemampuan dan daya saing Usaha Mikro, Kecil, dan Menengah. Peranan pemerintah daerah khususnya pemerintah kabupaten atau kota sebagai fasilitator sangat penting dalam pengembangan UMKM. Fasilitasi sendiri terdapat tiga indikator yaitu:

\section{Sarana dan Prasarana}

Menurut (Moenir, 1992) mengatakan sarana merupakan seperangkat peralatan atau perlengkapan kerja yang bisa dipergunakan saat proses pekerjaan. Sedangkan prasarana menurut KBBI yaitu sesuatu yang sebagai penunjang utama dari terselenggaranya proses kegiatan atau pekerjaan (Indonesia, 2002). Dalam hal ini, untuk memberikan fasilitas dalam kegiatan pengembangan UMKM handycraft limbah kayu jati sebagai produk unggulan Kabupaten Bojonegoro pemerintah daerah sudah memfasilitasi sarana dan prasarana. Fasilitas sarana prasarana dalam hal ini pemerintah Kabupaten Bojonegoro pertama, sudah memfasilitasi dari sarana dan prasarana tempat pameran produk.

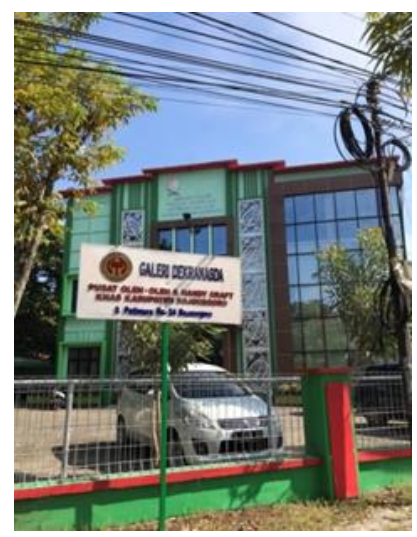

Gambar 2 Gedung Dekranasda

Sumber: Dokumentasi peneliti 2020 
Fasilitas yang diberikan untuk mewadahi produk-produk UMKM yang ada di Bojonegoro khususnya Handycraft limbah kayu jati ini Dinas Koperasi dan Usaha Mikro mendirikan gedung Galeri Dekranasda Bojonegoro yaitu pusat produk unggulan dan oleh-oleh Kabupaten Bojonegoro sebagai ajang pamer produk-produk unggulan daerah yang dapat meningkatkan pemasaran. Kedua, tempat untuk pelatihan baik itu di aula dinas terkait ataupun kantor kecamatan yang menjadi pelaksanaan kegiatan pelatihan perajin handycraft kayu jati di Kasiman.

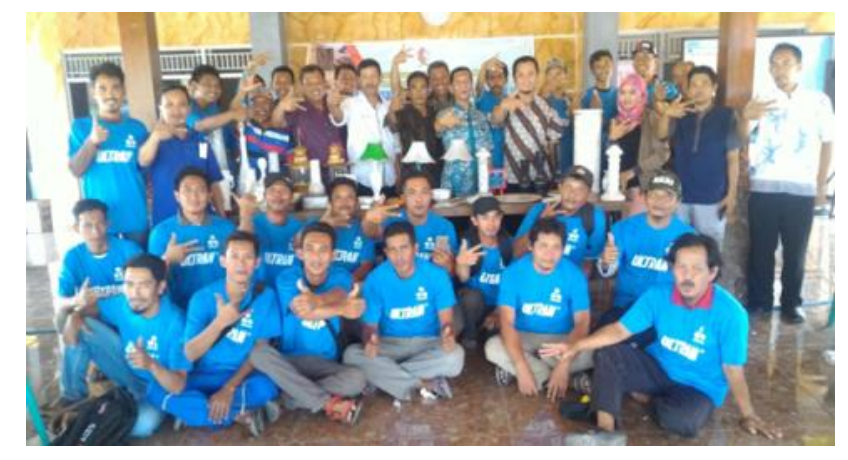

\section{Gambar 3 \\ Kegiatan pelatihan}

\section{Pelatihan SDM}

Menurut (Hamalik, 2000) Pelatihan adalah suatu proses serangkaian upaya yang dilaksanakan dengan sengaja dalam bentuk pemberian bantuan kepada tenaga kerja yang dilakukan oleh tenaga professional kepelatihan dalam satuan waktu yang bertujuan untuk meningkatkan kemampuan kerja peserta dalam bidang pekerjaan tertentu guna meningkatkan efektivitas dan produktivitas dalam suatu organisasi. Pemberian pelatihan SDM kepada UMKM handycraft limbah kayu jati di Kecamatan Kasiman selalu dilaksanakan oleh pemerintah Kabupaten Bojonegoro sesuai dengan dinas terkait. Hal ini dibuktikan bahwa adanya agenda tahunan yaitu dua kali dalam setahun dan kegiatan berlangsung tiga sampai satu minggu. Peserta pelatihan dihadiri khususnya untuk para pelaku UMKM handycraft limbah kayu jati yang ada di Kasiman. 


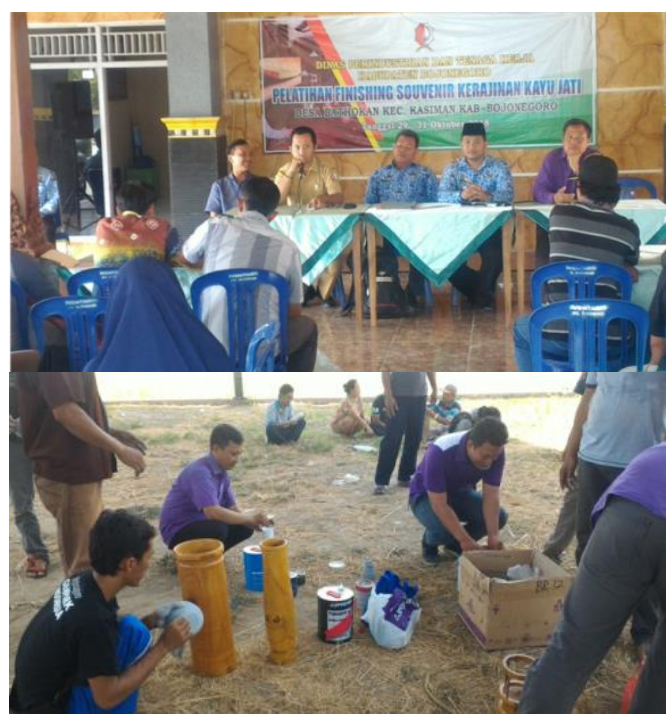

Gambar 4

\section{Kegiatan Pelatihan Finishing Souvenir (Handycraft)}

Limbah Kayu Jati di Kecamatan Kasiman

Sumber: Dinas Perindustrian Bojonegoro

Pelatihan yang sudah diberikan yaitu mengenai Finishing produk kerajinan kayu jati dan pelatihan pemanfaatan limbah kayu jati baik itu dari pengecatan, bentuk ukir-ukiran dan model atau bentuk produk. Dengan mendatangkan tenaga ahli baik itu dari pihak internal Dinas Perindustrian Kabupaten Bojonegoro ataupaun dari Romansa Furniture Ngawi selaku pelaku usaha industry kayu. Sehingga adanya kerjasama antara pemerintah daerah atau dinas-dinas terkait dengan pihak luar yang mendukung dari kegiatan pelatihan.

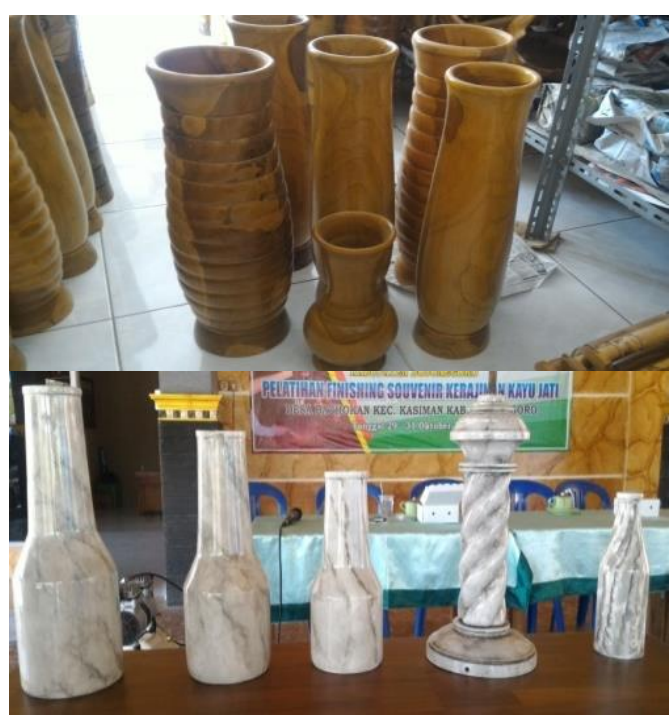

Gambar 5

Hasil Pelatihan Model Finishing Handycraft Limbah Kayu Jati

Sumber: Dokumentasi Dinas Perindustrian Bojonegoro 


\section{Promosi atau Pemasaran}

Fasilitas promosi atau pemasaran merupakan upaya pemerintah kabupaten Bojonegoro dalam pengembangan UMKM handycraft limbah kayu jati di Kecamatan Kasiman. Menurut KBBI pemasaran yaitu cara, proses, kegiatan dalam mempromosikan barang kepada masyarakat luas. Pemasaran merupakan suatu kegiatan yang dilakukan para pelaku usaha untuk mempromosikan suatu produk. Promosi yang sudah dilaksanakan dalam memperkenalkan produk handycraft limbah kayu jati sebagai produk unggulan Kabupaten Bojonegoro yaitu melalui online seperti media sosial seperti instagram atau promosi melalui aplikasi BBI (Bangga Buatan Indonesia) dan aplikasi DOLAN. Berikut produk-produk handycraft limbah kayu jati yang banyak diminati oleh masyarakat yaitu sebagai berikut:

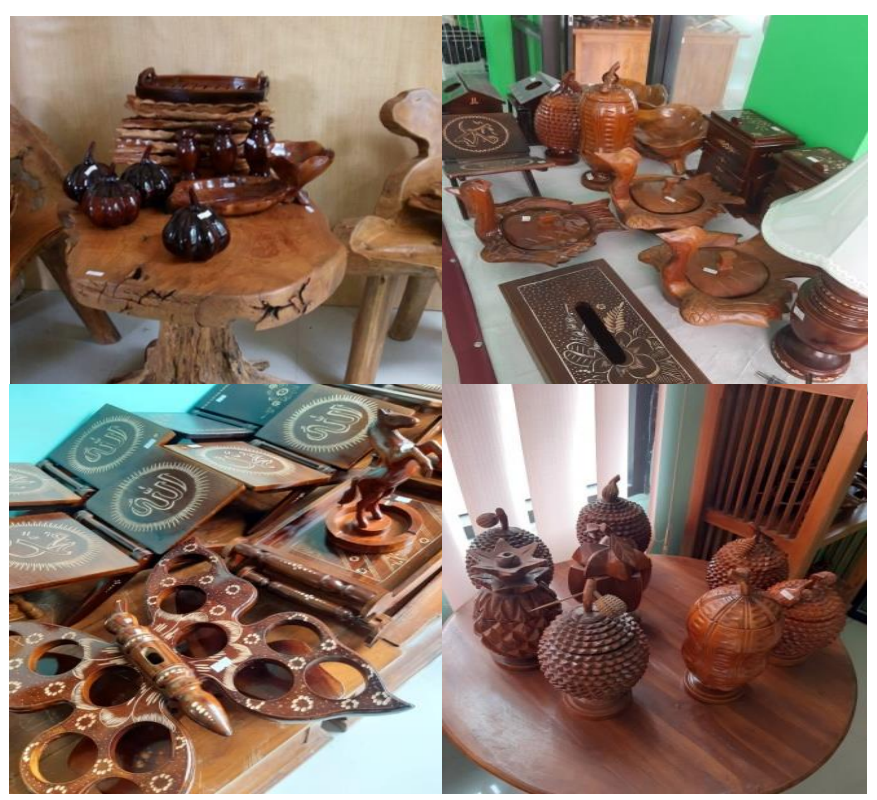

\section{Gambar 6}

\section{Kegiatan Pameran}

Sumber: Dokumentasi Peneliti 2020

Selanjutnya yaitu melalui kegiatan pameran baik tingkat kabupaten, provinsi ataupun nasional. Dengan ikut sertanya kegiatan pameran baik lokal ataupun nasional akan memberikan wawasan atau informasi bagi perajin ataupun pemerintah daerah sendiri untuk mengembangkan produk UMKM nya dari berbagai kalangan yang dapat meningkakan produktivitas serta ideide kreatif perajin dalam membuat desain-desain baru yang diminati oleh pasar. Selain itu juga adanya bentuk dukungan promosi dari pemerintah daerah melalui penitipan produk UMKM ke Galeri Dekranasda Bojonegoro dan Mall Pelayanan Publik. Sehingga dari adanya fasilitas promosi ini dapat meningkatkan penjualan dari perajin handycraft limbah kayu jati. 
Peran Pemerintah Daerah dalam Pengembangan Usaha Mikro Kecil dan Menengah (UMKM) "Handycraft" Limbah Kayu Jati Sebagai Produk Unggulan Kabupaten

Bojonegoro

Berdasarkan respon pelaku UMKM handycraft limbah kayu jati di Kecamatan Kasiman dan fasilitas baik sarana prasarana, pelatihan SDM dan fasilitas promosi atau pemasaran menurut hasil dari wawancara dan dilakukannya observasi oleh peneliti di lokasi penelitian, fokus pertama mengenai peran pemerintah sebagai Fasilitator bisa dikatakan sudah berperan. Hal ini merupakan bentuk dari peran pemerintah dalam memfasilitasi dan memotivasi pelaku UMKM untuk mengembangkan usahanya dan mampu bersaing.

\section{B. Peran Pemerintah Daerah sebagai Regulator}

Peran pemerintah sebagai regulator yaitu pemerintah mempersiapkan arah sebagai penyeimbang penyelenggaraan pembangunan dengan membuat suatu peraturan atau kebijakan bertujuan untuk meningkatkan efektivitas serta tertib dalam administrasi pembangunan. Dalam penelitian ini, fungsi regulator dalam menentukan peraturan dan kebijakan guna mendukung jalannya proses pengembangan dan pemberdayaan UMKM.

Pemerintah Kabupaten Bojonegoro dalam hal ini sudah menjalankan fungsinya sebagai regulator khususnya Dinas Perindustrian serta Dinas Perdagangan, Koperasi, dan Usaha Mikro yaitu yang Pertama, berdasarkan Peraturan Bupati Bojonegoro Nomor 57 Tahun 2020, yang berisi tentang penjelasan tugas, fungsi dan tata kinerja Dinas Perindustrian Kabupaten Bojonegoro. Dalam hal ini telah diimplementasikan pembinaan serta pengembangan UMKM handycraft berupa pemberian (a) sarana dan prasarana seperti tempat pelatihan, (b) memberikan pelatihan SDM, dalam memfinishing produk (c) fasilitas promosi melalui kegiatan pameran atau study banding.

Kedua, berdasarkan Peraturan Bupati Bojonegoro Nomor 59 Tahun 2020 yang berisi mengenai tupoksi serta tata kerja dari Dinas Perdagangan, Koperasi dan Usaha Mikro Kabupaten Bojonegoro. Dalam hal ini dinas terkait sebagai pemerintah daerah mempunyai tugas merencanakan, melaksanakan, pengawasan, penyelenggaraan pembinaan dan mengoordinasikan kegiatan pengembangan dan pemberdayaan UMKM salah satunya handycraft limbah kayu jati di Kecamatan Kasiman. Dalam bidang promosi atau pemasaran pada pasal 10 ayat 2 yaitu menyelenggarakan kegiatan pemasaran dan misi dagang bagi produk unggulan melalui pameran lokal, nasional dan internasional. Hal ini sudah diimplementasikan melalui kegiatan promosi produk baik itu melalui pameran kabupaten, provinsi dan nasional atau dengan system online melalui sosial media dan juga aplikasi-aplikasi seperti BBI dan DOLAN.

Ketiga, Peraturan Daerah Kabupaten Bojonegoro No. 23 Tahun 2018 tentang Rencana Pembangunan Jangka Menengah (RPJMD) Kabupaten Bojonegoro tahun 2018-2023. Keempat, Peratutan Bupati Bojonegoro Nomor 56 Tahun 2019 tentang Penjabaran APBD Bojonegoro Tahun 2020. Dilihat dari peraturan atau kebijakan sudah direncanakan dan diimplementasikan yang menjadi pedoman dalam menjalankan kegiatan atau program kerja. Sehingga 
dapat disimpulkan bahwa pemerintah daerah Kabupaten Bojonegoro dalam pengembangan UMKM handycraft limbah kayu jati sebagai produk unggulan Kabupaten Bojonegoro dalam hal peran pemerintah sebagai regulator sudah berperan. Dalam menjalankan peran pemerintah sebagai regulator adapun pembagian wewenang suatu kebijakan baik itu pemerintah pusat dan pemerintah daerah. Pemerintah daerah juga mempunyai wewenang dalam mengatur masyarakat dan daerahnya.

\section{Peran Pemerintah Daerah sebagai Katalisator}

Katalisator menurut KBBI merupakan seseorang atau sesuatu yang menyebabkan terjadinya perubahan dan menimbulkan kejadian baru atau mempercepat suatu peristiwa. Peran pemerintah sebagai Katalisator yakni pemerintah dalam hal ini berada diposisi sebagai aktor yang mempercepat pengembangan suatu daerah . Berdasarkan hal tersebut peran pemerintah daerah sebagai katalisator dalam pengembangan UMKM adalah mempercepat proses atau upaya untuk melaksanakan kegiatan mendukung pengembangan UMKM baik itu meningkatkan mutu produk ataupun meningkatkan dari segi permodalan dan dana anggaran untuk pelaksanaan setiap kegiatan pengembangan UMKM.

\section{Permodalan}

Modal merupakan hal yang sangat penting dalam suatu usaha, dengan tidak adanya modal usaha tidak akan bergerak dan berkembang. Permodalan ini dibutuhkan dari usaha kecil sampai dengan usaha yang sudah skala besar. Dalam permodalan UMKM handycraft limbah kayu jati ini, pemerintah daerah pernah memiliki program bantuan tunai kepada pelaku UMKM akan tetapi tidak berjalan sampai saat ini hal ini dikarenakan dari beberapa factor sehingga program bantuan tidak bisa dilanjutkan. Sehingga para pelaku UMKM untuk mendapatkan modal ini pihak pemerintah hanya menjembatani untuk melakukan pinjaman ke bank daerah atau BUMD.

\section{Tekonologi}

Teknologi adalah sarana sebagai penyedia barang yang dibutuhkan bagi manusia. Digunakanya teknologi ini berawal dari proses berubahnya SDA menjadi suatu alat sederhana. Sebagai alat, teknologi dipergunakan dalam memproduksi atau membuat suatu barang seperti halnya mesin. Dalam hal ini peran pemerintah daerah dalam pengembangan UMKM handycraft limbah kayu jati dengan diberikannya alat atau teknologi untuk mempercepat proses produksi yang dapat meningkatkan mutu kualitas produk dan meningkatkanya produktivitas. Akan tetapi program bantuan alat produksi ini juga pernah dilaksanakan oleh pemerintah daerah maupun kementrian yang akhirnya tidak berjalan sampai sekarang karena penggunaan seperti alat bubut, gerinda, resin tidak digunakan dengan bijak.

\section{Anggaran Dana}

Berdasarkan UU No.20 Tahun 2008 Pembiayaan adalah penyediaan dana oleh Pemerintah, Pemerintah Daerah, Dunia Usaha, dan masyarakat 
Peran Pemerintah Daerah dalam Pengembangan Usaha Mikro Kecil dan Menengah (UMKM) "Handycraft” Limbah Kayu Jati Sebagai Produk Unggulan Kabupaten

Bojonegoro

melalui bank, koperasi, dan lembaga keuangan bukan bank, untuk mengembangkan dan memperkuat permodalan Usaha Mikro, Kecil, dan Menengah. Setiap bentuk kegiatan atau fasilitas dan program kerja memerlukan adanya pembiayaan. Dari hasil penelitian bentuk dana ini sudah digunakan oleh pemerintah Kabupaten Bojonegoro melalui APBD untuk seluruh kegiatan pengembangan UMKM dari pengadaan kegiatan pelatihan, penyewaan narasumber, uang saku peserta, konsumsi, perlengkapan kegiatan pelatihan bahkan juga untuk kegiatan anggaran kegiatan pameran. Menurut hasil wawancara dan observasi peran pemerintah sebagai katalisator sudah cukup berperan, hal ini dibuktikan dari bentuk upaya pemerintah Kabupaten Bojonegoro dari beberapa indikator meskipun ada yang sudah tidak berjalan.

\section{Kesimpulan}

Dari hasil penelitian tentang pengembangan UMKM handycraft limbah kayu jati sebagai produk unggulan Kabupaten Bojonegoro, maka dapat diambil kesimpulan bahwa terdapat peran pemerintah yaitu pemerintah sebagai fasilitator, regulator dan katalisator. Pertama, Peran Pemerintah Kabupaten Bojonegoro sebagai fasilitator melalui berbagai kegiatan yang meliputi pemberian fasilitas sarana dan prasarana baik itu tempat pelatihan, tempat pameran perajin handycraft kayu jati dan gedung pameran yaitu Galeri Dekranasda Bojonegoro sebagai pusat promosi produk-produk unggulan UMKM salah satunya handycraft limbah kayu jati selain itu juga ada di Mall Pelayanan Publik Bojonegoro. Fasilitas pelatihan sumber daya manusia tentang pelatihan finishing produk baik itu model, motif ukiran ataupun finishing pengecatan produk dan desain produk yang dapat meningkatkan mutu hasil produksi serta kreativitas perajin dalam membuat desain-desain baru yang lebih diminati pasar. Dan fasilitas promosi atau pemasaran dengan melakukan promosi produk melalui system online seperti media sosial instagram akun @galeribojonegoro dan melalui aplikasi misalnya BBI atau DOLAN. Tidak hanya itu sarana fasilitas promosi juga dilakukan dengan kegiatan pameran baik itu tingkat Kabupaten, Provinsi, Nasional ataupun juga promosi melalui Galeri Dekranasda dan Mall Pelayanan Publik. Sehingga pemerintah daerah sebagai fasilitator sudah berperan dalam pengembangan UMKM dan meningkatkan produktivitas, kreativitas dan penjualan produk.

Kedua, Peran Pemerintah Kabupaten Bojonegoro sebagai regulator yaitu merencanakan, melaksanakan dan evaluasi suatu kebijakan atau peraturan. Melalui tugas pokok, fungsi yang sudah ada dalam peraturan Bupati serta peraturan tentang pelaksanaan APBD pemerintah kabupaten Bojonegoro melaksanakan tugas pokok dan fungsinya sebagai pedoman dalam pelaksanaan program kerja yaitu kegiatan pengembangan UMKM handycraft limbah kayu jati sebagai produk unggulan di Kabupaten Bojonegoro. Sehingga dengan peran pemerintah daerah Kabupaten Bojonegoro sebagai regulator sudah berperan sesuai dengan kebijakan yang ada.

Dan Ketiga, peran Pemerintah Kabupaten Bojonegoro sebagai katalisator yaitu dari melalui pemberian bantuan permodalan yang sudah tidak berjalan melainkan 
Marantika Fibrianti Sumadi dan Ananta Prathama

pemerintah masih menjembatani para pelaku UMKM dalam mencari modal ke bank daerah atau BUMD, pemberian bantuan teknologi juga sudah tidak ada, dan pengguanaan anggaran dana dari APBD yang digunakan untuk pelaksanaan kegiatan pengembangan UMKM sehingga peran pemerintah daerah sebagai regulator sudah cukup berperan. 
Peran Pemerintah Daerah dalam Pengembangan Usaha Mikro Kecil dan Menengah (UMKM) "Handycraft” Limbah Kayu Jati Sebagai Produk Unggulan Kabupaten

Bojonegoro

\section{BIBLIOGRAFI}

Agro Bisnis. (2019). Bojonegoro Pusat Kerajinan Kayu Jati Jawa Timur.

Ali, Mohammad. (2009). Pendidikan untuk pembangunan nasional: menuju bangsa Indonesia yang mandiri dan berdaya saing tinggi. Grasindo. Google Scholar

Badan Pusat Statistika. (2011). Luas Hutan Jati Kabupaten Bojonegoro.

Hamalik, Oemar. (2000). Pengembangan SDM: Manajemen Pelatihan Ketenagakerjaan. Pendekatan Terpadu, Cetakan, 1. Google Scholar

Indonesia, Departemen Pendidikan Nasional. (2002). Kamus besar bahasa Indonesia. Google Scholar

Moenir, H. A. S. (1992). Manajemen Pelayanan Indonesia. Jakarta: Bumi Aksara. Google Scholar

Moleong, Lexy J. (2017). Metodologi penelitian kualitatif (Revisi). Bandung: PT Remaja Rosdakarya. Google Scholar

Putra, Taranggana Gani. (2016). Peran Pemerintah Daerah Dan Partisipasi Pelaku Usaha Dalam Pengembangan UMKM Manik-Manik Kaca di Kabupaten Jombang. Kebijakan Dan Manajemen Publik, 3(April), 1-10. Google Scholar

Sugiyono, P. D. (2012). Metode Penelitian Kuantitatif Kualitatif Dan R\&D (Vol. 8). Alfabeta. Bandung.

Sugiyono, Prof. (2015). Metode penelitian kombinasi (mixed methods). Bandung: Alfabeta, 28. Google Scholar

\section{Copyright holder:}

Marantika Fibrianti Sumadi dan Ananta Prathama (2021)

First publication right:

Journal Syntax Literate

This article is licensed under:

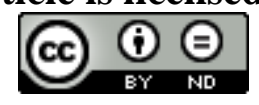

